was formed, and it was concludea mat only about 4 per cent of the material of mitochondria consists of lipines, the rest of the fatty material being true fat.

Bensley's conclusions differ so widely from those of previous students of the same subject that one looks for a possibility of reconciliation. May it not be that lipines are present in the ether-soluble fraction of mitochondrial substance in considerable amount, but largely resist precipitation by acetone ? Ciaccio $^{5}$ has especially stressed the solubility of lipines in acetone when other fatty or fat-soluble substances are also present, and Kaufmann and Lehmann $^{6}$ have shown that if $2 \cdot 1 \mathrm{gm}$. of oleic acid be added to 45 c.c. of acetone covering $2 \mathrm{gm}$. of lecithin, about half the lecithin goes into solution.

It would be most helpful if those who are expert in the technique of isolating mitochondrial material in quantity from cavy liver could be persuaded to apply tests for lipines to the large fraction of fatty material that is not precipitated by acetone.

Department of Zoology and JOHN R. BAKER.
Comparative Anatomy,
University Museum,
Oxford.
May 4.
1 Regaud, C., C.R. Soc. Biol., 65, 718 (1908).
' Regaud, C., C.R. Acad. Sci., 148, 861 (1909).
' Bensley, R. R., and H.oerr, N. L., Anat. Rec., 60, 449 (1934).
' Bensley, R. R., Anat. Rec., 68, 341 (1937).
' Ciacco, C., see Lison, L., “Histochimie animale"' (Paris, 193u), 206-208.
' Kaufmann, C., and Lehmann, E., Centralbl. allg. Path., 37, 145 (1926).

' Kaufmann, C., and Lehmann, E., Centralbl. allg. Path., 37, 145 (1926).

\section{Reversible Quenching by Oxygen of the Fluorescence of Polycyclic Hydrocarbons}

WE regret that, as Dr. E. J. Bowen has pointed out $^{1}$, the important paper of Bowen and Williams ${ }^{2}$ on the photo-oxidation of aromatic hydrocarbons has indeed escaped our notice, but we hope that our previous communication ${ }^{3}$ has served a useful purpose in directing attention to the occurrence of the phenomenon in the visible fluorescence of cancerogenic hydrocarbons where it has not hitherto been described. This reaction is not only of practical importance for analytical fluorescence measurements, but also of theoretical interest as a possible initial stage in the metabolic oxidation of these substances.

Cancer Research Laboratory H. WELL-MALHERBE.

North of England Council of the

British Empire Cancer Campaign,

Royal Victoria Infirmary.

JOSEPH WEISS.

Department of Chemistry, King's College,

University of Durham,

Newcastle-upon-Tyne.

$$
\text { May } 12 .
$$

1 Bowen, E. J., Nature, 149, 528 (1942).

${ }^{2}$ Bowen, E. J., and Williams, A. H., Trans. Faraday Soc., 35, 755 (1939).

${ }^{3}$ Weil-Malherbe, H., and Weiss, J., NATURE, 149, 471 (1942).

\section{Determination of Water in Soils}

THE usual method for determination of water in soils (that is, heating to $110^{\circ} \mathrm{C}$.) is almost always unsatisfactory owing to decomposition and slow oxidation of organic matter ; moreover the determination takes a long time to complete.
A series of experiments have therefore been carried out using the method described by Lowndes ${ }^{1}$, using a Dean and Stark's tube. The sample is thus distilled under xylene or toluene (b.p. $137^{\circ}$ and $110.7^{\circ}$ ), the water which comes over being weighed or its volume read off. The determination is completed in 2-4 hours and losses due to oxidation are avoided.

It will be seen that the results for a well-cultivated loamy garden soil are consistent among themselves and that the results with toluene agree with those obtained with xylene. With samples of chalk it was possible to apply a check by oven-drying, showing that the method is working satisfactorily.

Results with a dark clay loam

\begin{tabular}{|c|c|c|c|c|}
\hline Sample & $\begin{array}{c}\text { Appt. } \\
\text { no. }\end{array}$ & $\begin{array}{l}\text { Liquid } \\
\text { used }\end{array}$ & $\begin{array}{c}\text { Water } \\
\text { (\% dry wt.) }\end{array}$ & Average $\%$ \\
\hline IV & $\begin{array}{l}3 \\
6 \\
5\end{array}$ & $\begin{array}{c}\text { Xylene } \\
,, \\
,,\end{array}$ & $\left.\begin{array}{l}8 \cdot 5 \\
8 \cdot 3 \\
8 \cdot 0\end{array}\right\}$ & $8 \cdot 3$ \\
\hline \multirow[t]{2}{*}{ VIII } & $\begin{array}{l}3 \\
6\end{array}$ & $\begin{array}{c}\text { Xylene } \\
,,\end{array}$ & $\left.\begin{array}{l}21 \cdot 2 \\
21 \cdot 2\end{array}\right\}$ & $21 \cdot 2$ (with xylene) \\
\hline & $\begin{array}{l}8 \\
4\end{array}$ & $\begin{array}{c}\text { Toluene } \\
,,\end{array}$ & $\left.\begin{array}{l}21 \cdot 7 \\
21 \cdot 9\end{array}\right\}$ & $21 \cdot 8$ (with toluene) \\
\hline I, $a$ & $\begin{array}{l}9 \\
5 \\
3\end{array}$ & $\begin{array}{c}\text { Xylene } \\
, " \\
, "\end{array}$ & $\left.\begin{array}{l}33 \cdot 5 \\
33 \cdot 8 \\
33 \cdot 6\end{array}\right\}$ & $33 \cdot 6$ \\
\hline \multirow[t]{2}{*}{$\mathbf{v}$} & $\begin{array}{l}3 \\
6\end{array}$ & $\begin{array}{c}\text { Xylene } \\
,,\end{array}$ & $\left.\begin{array}{l}56 \cdot 3 \\
55 \cdot 3\end{array}\right\}$ & $55 \cdot 8$ (with xylene) \\
\hline & $\begin{array}{l}8 \\
5\end{array}$ & $\begin{array}{c}\text { Toluene } \\
,,\end{array}$ & $\left.\begin{array}{l}56 \cdot 4 \\
55 \cdot 3\end{array}\right\}$ & 55.9 (with toluene) \\
\hline
\end{tabular}

Results with chalk (using xylene)

\begin{tabular}{|c|c|c|}
\hline Appt. no. & $\begin{array}{c}\text { Water } \\
\text { (\% dry wt.) }\end{array}$ & $\begin{array}{c}\text { \% water (by oven } \\
\text { drying at 110 })\end{array}$ \\
\hline 1 & $23 \cdot 8$ & $24 \cdot 8$ \\
2 & $23 \cdot 5$ & $24 \cdot 4$ \\
2 & $22 \cdot 2$ & $22 \cdot 4$ \\
2 & $13 \cdot 2$ & $13 \cdot 5$ \\
3 & $7 \cdot 2$ & $7 \cdot 0$ \\
\hline
\end{tabular}

These results have not been corrected for the small amount of water left on the walls of the apparatus, which amounts to about $0.1 \mathrm{gm}$. but varies with the construction of the tube.

Further work is in progress on the application of this method to the investigation of soil moisture, but as there seems to be no doubt of its suitability and obvious advantages for most purposes, it was felt that the above preliminary results were worth putting on record.

The Science Schools,

G. H. LOCKeT.

W. H. BARretT.

Harrow School. May 5.

${ }^{1}$ NATURE, 148, 594 (1941).

\section{Molecular Sodium Hydride in Interstellar Space}

IN a recent article ${ }^{1}$ describing results obtained with the coudé spectrograph of the Mount Wilson Observatory, W. S. Adams gives some details of the identification of a number of interstellar lines with absorption lines of various molecules in their lowest possible energy states. Among others he mentions a line at $\lambda 3934 \cdot 3$ provisionally assigned to $\mathrm{NaH}$ by $\mathrm{McKellar}^{2}$.

Now the hydrides of the alkali metals are char. acterized by spectra containing band systems of rather 